\title{
A New Allogromiid Genus (Rhizopoda: Foraminiferida) from the Vellar Estuary, Bay of Bengal
}

\author{
ANDREW J. GOODAY \\ Institute of Oceanographic Sciences, \\ Brook Road, Wormley, \\ Godalming, Surrey, GU8 5UB. U.K.
}

\author{
OLIVIA J. FERNANDO \\ Centre of Advanced Study in Marine Biology, \\ Porto Novo 608502 , \\ Tamil Nadu, India.
}

\begin{abstract}
This paper reports what we believe to be the first record of allogromiid foraminifers from coastal Indian waters. Two species from the Vellar Estuary on the east coast of India south of Madras are described and placed in a new genus Vellaria. The foraminifers live at or near the sediment-water interface and are characterised by the development of a flared, conical or trumpet-shaped apertural structure which apparently serves to attach the test to small sand grains. Allogromiids are delicate and inconspicuous organisms which may be more widespread in esturine and brackish water settings than is currently realised. J. Micropalaeontol., 11 (2): 233-239, December 1992.
\end{abstract}

\section{INTRODUCTION}

The suborder Allogromiina includes foraminifers ("allogromiids") in which the test wall is membranaceous or proteinaceous, sometimes with a thin outer veneer of agglutinated particles (Brnnimann et al. 1979; Loeblich and Tappan 1987; Rhumbler 1904). Members of this taxon typically have a simple, sack or flask-like test morphology (Loeblich and Tappan 1987). Although widely distributed and sometimes common, allogromiids remain rather poorly known. Of the 2455 living and fossil foraminiferal genera recognised by Loeblich and Tappan (1987), only 56 are members of this taxon. Almost three-quarters (40) of these genera were first described from either European fresh-water or coastal marine sites or from the North Atlantic (Loeblich and Tappan 1987). The remainder originate from the coasts of North and South America and the Pacific Ocean.

This paper presents what we believe to be the first record of allogromiids from Indian coastal waters. Two species, both assigned to the new genus Vellaria, are described from the Vellar Estuary on the east coast of India. The foraminiferal fauna of this estuary was investigated by Ramanathan (1970) who recorded almost ninety species, more than $95 \%$ of them calcareous and the remainder agglutinated. Foraminifera have also been studied in other brackish water settings around the Indian coast, namely Thana Creek near Bombay (Setty 1982; Setty \& Nigam 1984), Vembaned Estuary and Kayamkulam Lake, SW India (Antony 1975, 1980; Antony \& Kurian 1975), lagoons near Cochin (Seibold \& Seibold 1981), and the Pennar, Godavari River and Suddagedda Estuaries in eastern India (Reddy \& Rao 1983, 1984;Narappa et al. 1981;Rao \& Rao 1975). Allogromiids were not explicitly reported in any of these studies. Antony $(1975,1980)$ mentions "chitinous" foraminifera but he appears to be referring to forms with agglutinated rather than proteinaceous tests.

Fully marine foraminiferal faunas have been described from the shelf off the west coast (Bhatia \& Kumar 1976; Nigam
1984; Sethulekshmi Amma 1958; Setty 1976, 1978; Setty et al. 1979; Setty \& Nigam 1980, 1982) and from the shelf and from beach sands along the east coast of India (Anantharaman 1971; Bhalla 1968, 1970; Hansa 1972; Kaladhar et al. 1990). These papers also deal exclusively with calcareous and agglutinated taxa.

\section{MATERIAL AND METHODS}

The specimens were collected in the estuary of the River Vellar, Bay of Bengal (11 29'N, $7946^{\prime} \mathrm{E}$; Station J1 of Fernando 1987), at a site where the sediment consisted of fine sand with a maximum silt content of $35.1 \%$ (mean particle size 2.25-3.55f). Full details of the sampling area are given by Fernando (1987) and Fernando \& Fernando (1988).

The samples were obtained using a corer of $2.8 \mathrm{~cm}$ internal diameter. This was pushed into the sediment by hand to a depth of $10 \mathrm{~cm}$ and closed with a rubber stopper before being removed. The sediment was washed through $500 \mathrm{~mm}$ and $63 \mathrm{~mm}$ mesh sieves. Material retained on the finer sieve was fixed and stored in $4 \%$ formaldehyde. After staining with Rose Bengal, meiofaunal organisms were sorted under a binocular microscope and separated using a fine tipped pipette.

The allogromiids were photographed in alcohol under reflected light using a Wild M400 photomicroscope or were mounted in a drop of glycerol and photographed under an Olympus model BHScompound photomicroscope. Linedrawings were made using a Wild M20 drawing tube. For permanent storage specimens were mounted in glycerine jelly Maybury et al. (1991). This proceedure led to some shrinkage and distortion of the test, particularly in Vellaria sacculus.

SYSTEMATIC DESCRIPTIONS

Order Foraminiferida Eichwald, 1835

Suborder Allogromiina Loeblich \& Tappan, 1961

Family Allogromiidae Rhumbler, 1904

Subfamily Allogromiinae Rhumbler, 1904 Vellaria gen. nov. 
Generic diagnosis. Test less than $1 \mathrm{~mm}$ in total length, symmetrically oval with a thin proteinaceous wall, in one species overlain by thin veneer of finely agglutinated particles, in another without agglutinated particles. Apertural end produced into strongly flared, approximately conical or bowl-shaped structure. Cytoplasm finely granular with single large nucleus.

Type species. Vellaria pellucida gen. et sp. nov..

Remarks. One of the two species placed in Vellaria has a finely agglutinated outer test layer. The presence of a sparse agglutinated coating is not incompatable with a placement in the suborder Allogromiina (Loeblich \& Tappan 1987, p.7). However, in view of the importance of wall structure in foraminiferal taxonomy (Loeblich \& Tappan 1988), this difference may eventually warrant separation of the two species at the generic level. For the present, they are regarded as congeneric because both possess a flared apertural extension. This feature distinguishes the new genus from Allogromia and similar allogromiid genera (Loeblich \& Tappan 1987). In some sublittoral Rhynchogromia species the apertural end is extended into a short neck (Golemansky 1991) but this is parallel-sided rather than flared.

The apertural region in Vellaria resembles that developed in some testate amoebae. The test of Sudzukiella marina, a species recently described from sublittoral sands off the French coast (Golemansky, 1991), is produced distally into a short, curved neck which attaches the organism to sand grains. In testate amoebae belonging to the family Psammonobiotidae, a short sucker-like funnel with a flexible periphery surrounds the aperture (Ogden \& Coteaux, 1989; Golemansky, 1990). Psammonobiotids are tiny interstitial organisms which live in the pore waters of coastal sands in many parts of the world (for example, Golemansky, 1974, 1982) and are characteristic of the contact zone between continental fresh water and sea water (Golemansky, 1990). Our organisms differ from psammonobiotids in their overall test shape, the much less regular shape of the apertural funnel, and the basically proteinaceous nature of the test wall.

They are also larger than either Sudzukiella or psammonobiontid species. However, since it is possible to confuse foraminifera with testate amoebae (Ogden \& Coteaux 1989), we are grateful to Dr C.G. Ogden (written communication August 1991) and to Professor V. Golemansky (personal communication, April 1992) for confirmation that our organisms are almost certainly allogromiids.

Vellaria pellucidus gen. et sp. nov.. (Fig.1; Pl.1, figs 1-8)

Derivation of name. Latin pellucidus, transparent; referring to the appearance of the test wall.

Diagnosis. Species of Vellaria $140-420 \mathrm{~mm}$ in length with

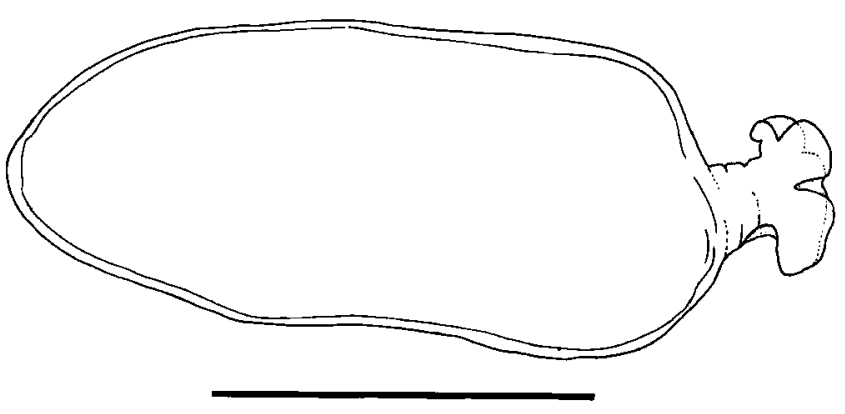

Fig. 1. Vellaria pellucidus gen. et sp. nov.. Holotypt on slide ZF 4983; the outer line represents the test wall, the inner line represents the edge of the protoplasm.

Scale $=200 \mathrm{~mm}$.

apertural end produced into short tube which ends in bowl-shaped expansion. Wall entirely organic.

Type material. ZF4983: Holotype (Fig.1) and 5 paratypes (Pl.1) mounted in glycerine jelly on glass slides.

Other material studied. 42 specimens.

Type locality. Vellar Estuary, near Porto Novo, SW India (Station J1 of Fernando 1987).

Description. The test ranges from $140 \mathrm{~mm}$ to $420 \mathrm{~mm}$ (mean $295+63 \mathrm{~mm}$ ) in length and $78 \mathrm{~mm}$ to $186 \mathrm{~mm}$ (mean $138+32 \mathrm{~mm}$ ) in width; length/height ratio $1.5-2.9$ (mean $2.1+0.3$ ). The lateral outline is approximately oval, generally widest in the distal half and tapering towards the proximal end which is either rounded or bluntly pointed. The sides of the test are gently curved and never concave. The test is usually plump and approximately circular in cross section but occasionally is distinctly flattened.

The apertural end is produced into a short tube giving rise to a broad, expanded, distal structure. This is often crumpled but in undistorted specimens it is shaped like a deep saucer. Small mineral grains may be attached to its outer margin. The tube and distal structure together measure $31-78 \mathrm{~mm}$ (mean $53+10 \mathrm{~mm}$ ) in total length.

The test wall is thin $(7-10 \mathrm{~mm})$, transparent and flexible. It is composed of proteinaceous material with no externally agglutinated particles. The protoplasm forms a transluscent, finely granular mass, with only a few indeterminate larger inclusions. There is usualy a narrow gap (about $15-30 \mathrm{~mm}$ ) between the wall and the protoplasm although in a few cases the protoplasmic mass has shrunk away from the wall. This is presumably an artifact. In one case a strand of protoplasm extends from the main mass into the apertural tube. There is no endosolenial tube. Many specimens have a single nucleus, $160-190 \mathrm{~mm}$ in diameter, with an optically denser outer region which gives it an annular appearance.

\section{Explanation of Plate 1}

Vellaria pellucidus gen. et sp. nov..

Fig. 1. Collection of specimens photographed in alcohol.

Scale $=500 \mathrm{~mm}$.

Figs 2-8. Specimens photographed in glycerol before mounting in glycerine jelly on slide ZF 4983. Fig. 2 is a detail of fig. 3 and shows the apertural structure with adhering sediment grains. Fig. 7 is a detail of fig. 5 and shows the nucleus. Scales $=100 \mathrm{~mm}(\mathrm{figs} 2-6,8)$ and $50 \mathrm{~mm}$ (fig.7). 

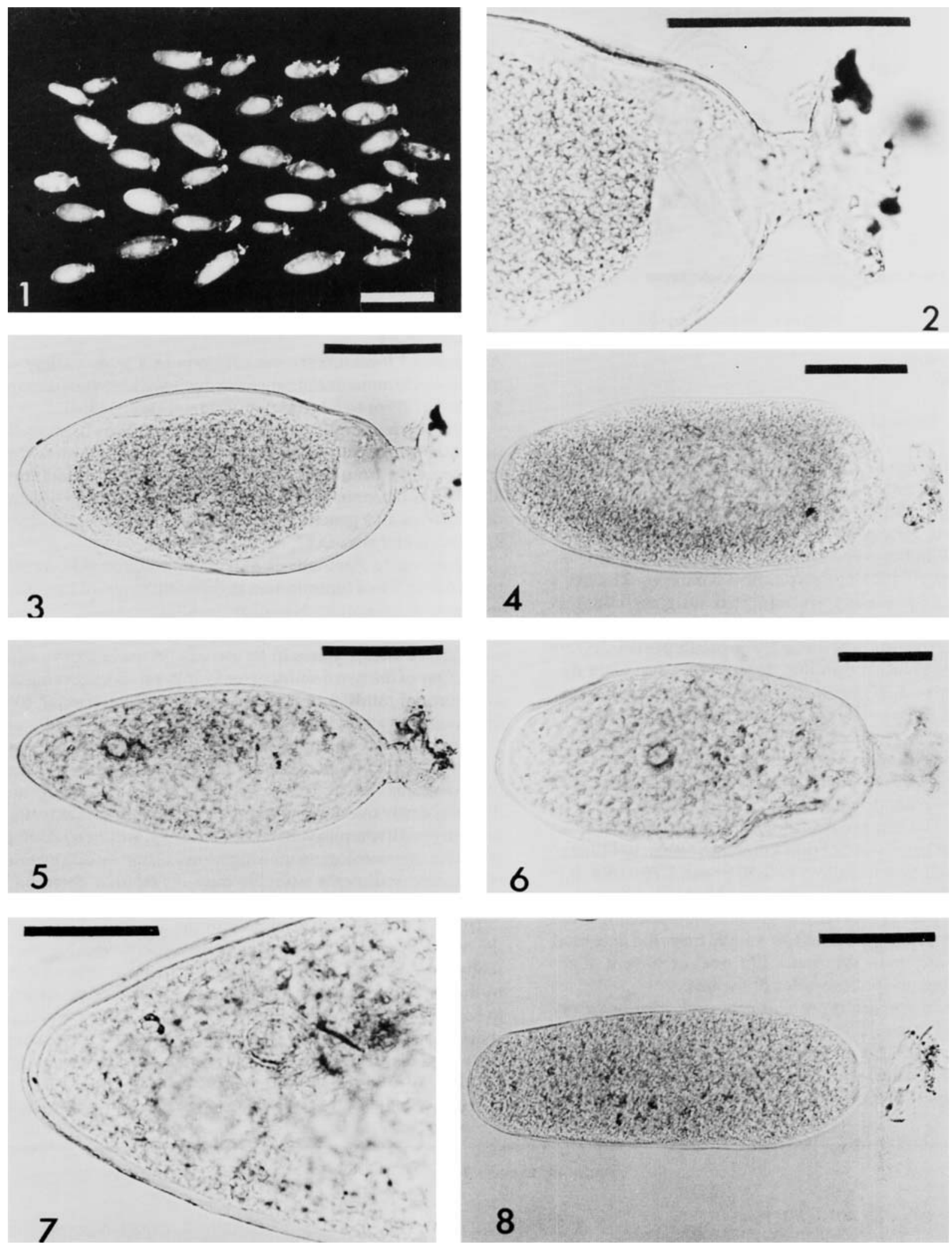


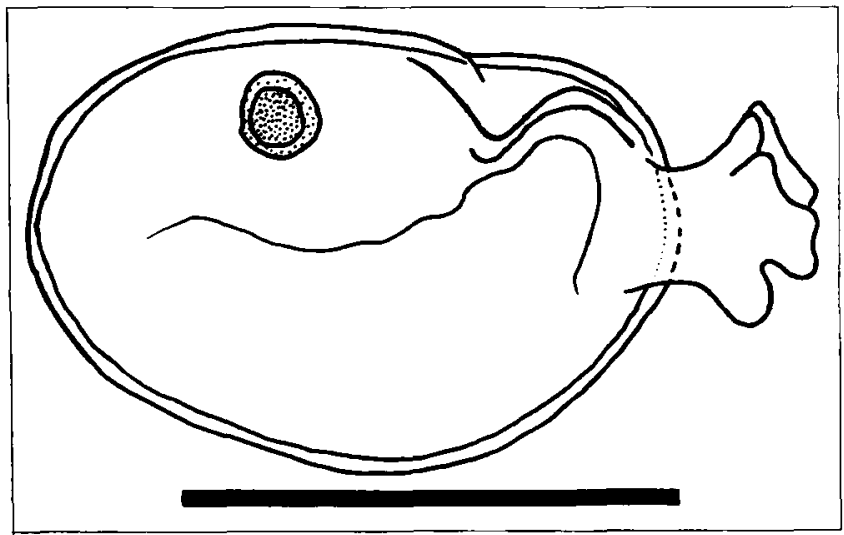

Fig. 2. Vellaria sacculus gen. et sp. nov.. Holotype on slide ZF 4984; the outer line represents the test wall, the inner line represents the edge of the protoplasm.

Scale $=100 \mathrm{~mm}$.

Vellaria sacculus gen. et sp. nov.

(Fig.2; Pl.2, figs 1-8)

Derivation of name. Latin sacculus, a little bag; referring to the shape of the test.

Diagnosis. Species of Vellaria $<200 \mathrm{~mm}$ long with apertural end produced into conical structure. Test wall basically organic but with thin veneer of finely agglutinated particles. Type material. ZF 4984: Holotype and 4 paratypes; ZF 4985: 8 paratypes. All specimens are mounted on glass slides in glycerine jelly which, in most cases, has caused considerable shrinkage and distortion of the test. The paratypes (Pl.2) were photographed before mounting. Because of subsequent distortion, the individual specimens can no longer be confidently recognised on the type slides. The holotype (Fig.2) was drawn after mounting on the type slide.

Other material studied. 33 specimens.

Type locality. Vellar Estuary, near Porto Novo, SW India (Station J1 of Fernando 1987).

Description. The test ranges from $117 \mathrm{~mm}$ to $195 \mathrm{~mm}$ (mean $158+21 \mathrm{~mm}$ ) in length and $62 \mathrm{~mm}$ to $166 \mathrm{~mm}$ (mean $93+12 \mathrm{~mm}$ ) in width; length:height ratio $1.23-2.50$ (mean $1.76+0.30$ ). It is basically flask shaped and approximately oval in lateral outline. In detail, the shape is rather variable. Most specimens are widest about a quarter of the test length from the apertural end. Others are more symmetrically oval or have a slight concavity along one or both sides of the test.

A few specimens are more elongate and approximately cylindrical in shape. In cross section, the test is circular or slightly flattened. The apertural end is produced out into flared, roughly conical structure, $20-40 \mathrm{~mm}$ (mean $30+3.8 \mathrm{~mm}$ ) long. In one specimen the aperture is attached to a large sand grain.

The test wall is thin (about $10-15 \mathrm{~mm}$ ), flexible, translucent and milky white in reflected light. It is composed of organic material with a thin but complete outer veneer of finely agglutinated particles. The protoplasm is finely granular. There are usually no large, identifiable inclusions although one specimen contains a diatom frustule.

There is no endosolenial tube. Most specimens contain a single nucleus, $90-120 \mathrm{~mm}$ diameter, with an optically denser outer region.

Remarks. Vellaria sacculus is smaller than V. pellucida and has a more rounded test outline, a flared apertural structure which arises directly from the test rather than 10 from the end of a short neck, and a distinct, agglutinated outer test layer.

\section{DISCUSSION}

Allogromiid foraminifera are common in a wide variety of marine environments ranging from deep-sea trenches (Jumars \& Hessler, 1976) to intertidal mudflats (Ellison, 1984).

Although frequently overlooked, allogromiids seem to be particularly common in estuaries and other brackish water environments around the world.Smitter (1956), Brnnimann et al. (1979) and Brnnimann \& Zaninetti (1984) described several new species and genera from mangrove swamps and other brackish water sites in SE Africa and Brazil.

According to Zaninetti et al. (1979), allogromiids constituted $6.9-18.5 \%$ of foraminifera in different zones of Brazilian mangrove swamps. Nyholm \& Olsson (1973) found monothalamous foraminifers, including allogromiids, to be common at three stations in an estuary on the Swedish west coast. One of the two dominant foraminiferal species living on an intertidal mudflat in the estuary of the River Tamar, SW England, was an undescribed allogromiid (Ellison 1984).

Poorly known rhizopod protozoans (e.g. Lieberkuhnia) which resemble allogromiids are also known from fresh water environments (Bovee 1985). Members of the new genus are delicate, easily overlooked organisms which certainly would be destroyed if samples were dried, a proceedure often adopted in micropalaeontological investigations. Careful examination of esturine sediments samples may reveal that these and similar delicate allogromiids are of widespread occurrence.

The allogromiids occured only in the superficial layers of the cores. Even after sieving, many specimens were attached to small sand grains, although by the time they were examined by the senior author, most had become detatched. Attachment to sand grains may allow them to retain a position near the sediment-water interface, a potential problem for these very light organisms, even in the very gentle current conditions which prevail in the Vellar Estuary. The algal and bacterial microflora which is often associated with sand grains may

\section{Explanation of Plate 2}

Vellaria sacculus gen. et sp. nov.

Fig.1. Collection of specimens photographed under alcohol.

Scale $=500 \mathrm{~mm}$.

Figs 2-8. Specimens photographed in glycerol prior to mounting in glycerine jelly on slides ZF 4984 and ZF 4985 . Fig. 4 shows a specimen attached to a small sand grain. Fig. 7 shows the nucleus. All scales $=50 \mathrm{~mm}$. 

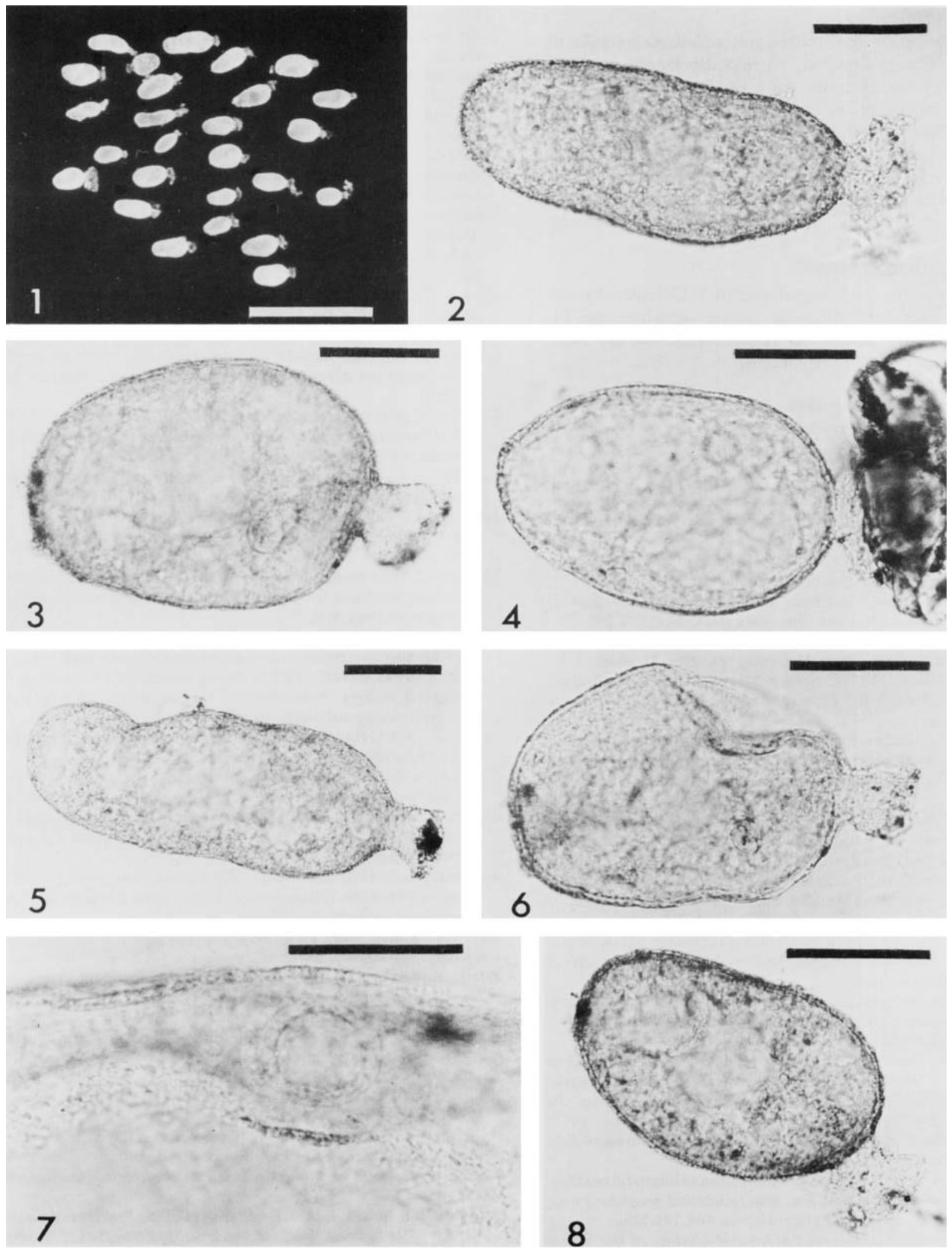
also provide a food source for the allogromiids (Anderson \& Meadows 1978).

As noted above, the apertural region of Vellaria is similar to that of some testate amoebae, particularly members of the Psammonobiotidae. In both cases, the aperture is used to attach the organism, at least temporarily, to sand grains and other hard substrates (Chardez 1984; Golemansky 1990). However, in other respects, the two taxa occupy different ecological niches. Psammonobiotids are interstitial protozoans which inhabit the pore waters of sandy coastal sediments whereas Vellaria lives at or near the surface of fine, silty esturine sands.

\section{ACKNOWLEDGEMENTS}

M.V. Angel critically read the manuscript, V. Golemansky and C.G. Ogden provided advice on testate amoebae, and M. Conquer carefully printed the photographs. We are most grateful to these people for their help.

\section{Manuscript received May 1992 \\ Manuscript accepted November 1992}

\section{REFERENCES}

Anantharaman,S. 1971. A study of the ecology of Recent Foraminifera of Palk Strait and Gulf of Mannar. Journal of the Annamalai University, 29, 183-198.

Anderson, J.G. \& Meadows, P.S. 1978. Microenvironments in marine sediments. Proceedings Royal Society Edinburgh, 76B, 1-16

Antony, A. 1975. Foraminifera from the Kayamkulam Lake. Bulletin Department of Marine Sciences, University of Cochin, 7, 257-262.

Antony, A. 1980. Foraminifera of the Vembanad estuary. Bulletin Department of Marine Sciences, University of Cochin, 11, 26-63.

Antony, A.\& Kurian, C.V.1975. Seasonal occurrence of Rotalia beccarii (Linn) in the Vembanad estuary. Bulletin Department of Marine Sciences, University of Cochin, 7,235-241.

Bhalla, S.N. 1967. Recent foraminifera from Vishakapatnam beach sands and its relation to the known foramgeographical provinces in the Indian Ocean. Bulletin National Institute of Sciences of India, 38, 376-392.

Bhalla, S.N. 1970. Foraminifera from marine beach sands, Madras, and faunal provinces of the Indian Ocean. Contrib. Cushman Foundation foraminiferal Research, 21, 156-163.

Bhatia, S.B. \& Kumar, S. 1976. Recent benthonic foraminifers from the inner shelf area around Anjidiv Island, off Binge, west coast of India. Maritime Sediments Special Publication, 1, 239-249.

Bovee, E.C. 1985. Order Athalmidia. In Lee, J.J., Hutner, S.H. \& Bovee, E.C. (Eds) , Illustrated Guide to the Protozoa, 246-252. Society of Protozoologists, Kansas.

Brnnimann, P.\&Zaninetti, L. 1984. Agglutinated Foraminifera mainly Trochamminacea from the Baia de Sepetiba, near Rio de Janeiro, Brazil. Revue de Palobiologie, Geneva, 3, 63-115

Brnnimann, P., Zaninetti, L. \& Moura, J.A. 1979. New Recent "allogromiine" and primitive textulariine foraminifera from brackish waters of Brazil. Notes du Laboratoire de Paleontologie del'Universite de Geneve, 4, 27-35, pls 1-5.

Chardez, D. 1984. Etude sur les Thcmoebiens du msopsammon. Acta Protozoologica, 23, 247-253.

Ellison, R.L.1984. Foraminifera and meiofauna on an intertidal mudflat, Cornwall, England: Populations; respiration and secondary production; and energy budget. Hydrobiologia, 109, 131-148.

Fernando, O.J. 1987. Studies on the intertidal fauna of the Vellar Estuary. Journal of the marine biological Association of India, 29, 86-103.
Fernando, O.J. \& Fernando, S.A. 1988. Intertidal sediment characteristics of Vellar Estuary. Mahasagar, 21, 245-251.

Golemansky, V. 1974. Psammonobiotidae fam. nov. - une nouvelle famille de thcamoebiens (Rhizopoda, Testacea) du psammal supralittoral des mers. Acta Protozoologica, 13, 137-141.

Golemansky, V. 1982. Revision du genre Ogdeniella nom. $n$. (=Amphorellopsis Golemansky, 1970) (Rhizopoda, Gromida) avec considerations sur son origine et evolution dans le milieu interstitiel. Acta Zoologica Bulgarica, Sofia, 19, 3-11.

Golemansky,V.1990. Interstitial testate amoebae(Rhizopoda: Testacea) from the Mediterranean basin. Stygologia, 5, 49-54.

Golemansky, V. 1991. Thecamoebiens msopsammiques (Rhizopoda: Arcellinida, Gromida \& Monothalamida) du sublittoral marin de l'Atlantique dans la rgion de Roscoff(France). Archiv fr Protistenkunde 140, 35-43.

Hamsa, K.M.S.A. 1972. Foraminifera of the Palk Bay and Gulf of Mannar. Journal of the Marine Biological Association of India, 14, 418-423.

Jumars, P.A. \& Hessler, R.R. 1976. Hadal community structure: implications from the Aleutian Trench. Journal of Marine Research, 34, 547-560.

Kaladhar, R., Kamalakaram, S., Varma, K.V. \& Bhaskara Rao, V. 1990. Recent Foraminifera from nearshore shelf, south of $V$ isakhapatnam, east coast of India. Indian Journal of Marine Sciences, 19, 71-73.

Loeblich, A.R. \& Tappan, H. 1987. Foraminiferal Genera and their Classification. van Nostrand Reinhold, New York, 970pp, 847pls.

Loeblich, A.R. \& Tappan, H. 1988. Implications of wall composition and structure in agglutinated foraminifers. Journal of Paleontology, 63(6), 769-777.

Maybury, C., Morrison, L. \& Stewart, V. 1991. The search for a reliable mounting medium for Recent "live" Foraminifera. Journal of Micropalaeontology, 9 (2), 172.

Narappa, K.V., Rao, M.S. \& Rao, M.P. 1981. Living Foraminiferida from the esturine complex of the Gautami and Nilarevu distributaries of the river Godavari - Part 1. Living populations in relation to ecological factors. Proceedings of the IX Indian Collogium on Micropaleontology and Stratigraphy, 49-68.

Nigam, R. 1984. Living benthonic foraminifera in a tidal environment: Gulf of Khambhat (India). Marine Geology, 58, 415-425.

Nyholm, K.-G. \& Olsson, I. 1973. Seasonal fluctuations of the meiobenthos in an estuary on the Swedish west coast. Zoon, 1, 69-76.

Ogden, C.G. \& Coteaux, M.-M. 1989. Interstitial marine rhizopods (Protozoa) from littoral sands on the east coast of England. European Journal of Protistology, 24, 281-290.

Ramanathan, R. 1970 Quantitative differences in the living benthic foraminifera of the Vellar estuary, Tamil Nadu. Journal of the Geological Society of India, 11, 127-141.

Rao, T,V. \& Rao, M.S. 1974. Recent foraminifera of Suddaggeda Estuary, east coast of India. Micropaleontology, 20, 398-419.

Reddy, K.R. \& Rao, R.J. 1983. Diversity and dominance of living and total foraminiferal assemblages, Pennar Estuary, Andhra Pradesh. Journal of the Geological Society of India, 24, 594-603.

Reddy, K.R. \& Rao, R.J. 1984. Foraminifera-salinity relationships in the Pennar Estuary, India. Journal of Foraminiferal Research, 14, 115-119.

Rhumbler, L. 1904. Systematische Zusammenstellung der recenten Reticulosa. Archiv fr Protistenkunde, 3, 181-294.

Seibold, I. and Seibold, E. 1981. Offshore and lagoonal benthic foraminifera near Cochin (Southwest India) distribution, transport, ecological aspects. Jahrbuch fr Geologie und Palontologie Abhandlungen, 162, 1-56.

Sethulekshmi Amma, J. 1958. Foraminifera of the Travencore Coast. Bulletin of the Research. Institute, University of Kerala, Ser. C, 6, 1-96. 
Setty, M.G.A.P. 1976. The relative sensitivity of benthonic foraminifera in the polluted marine environment of Cola Bay, Goa. Proceedings VIIndian Colloquium on Micropalaeontology and Stratigraphy, 225-234.

Setty, M.G.A.P. 1978. Shelf edge regime \& Foraminifera off Pondicherry, Bay of Bengal. Indian Journal of Marine Science, 7, 302-304.

Setty, M.G.A.P. 1982. Pollution effects monitoring with foraminifera as indices in the Thana Creek, Bombay area. Journal of Environmental Studies, 18, 205-209.

Setty, M.G.A.P., Nigam, R. \& Ambre, N.V. 1979. Graphic patterns of foraminiferal dominance in nearshore region of central west coast of India. Mahasagar - Bulletin of the National Institute of Oceanography, 12, 195-199.

Setty, M.G.A.P. \& Nigam, R. 1980. Microenvironments and anomalous foraminiferal distribution within the neritic regime of Dabhol-Vengurla section (Arabian Sea). Revista Italiana de Paleontologia e Stratigrafia, 86, 417-428.
Setty, M.G.A.P. \& Nigam, R. 1982. Foraminiferal assemblages and organic carbon relationship in benthic marine ecosystem of western Indian continental shelf. Indian Journal of Marine Sciences, 11, 225-232.

Setty, M.G.A.P. \& Nigam, R. 1984. Benthic foraminifera as pollution indices in the marine environment of the west coast of India. Revista Italiana de Paleontologia e Stratigrafi, 89, 421-436.

Smitter, Y.H. 1956. Chitinosaccus, a new foraminiferal genus of the Allogromiidae from Santa Lucia Bay, Zululand. South African Journal of Science, 52, 258-259.

Zaninetti, L., Brnnimann, P., Dias-Brito, D., Arai, M., Casaletti, P., Koutsoukos, E. \& Silveira, S. 1979. Distribution cologique des Foraminifres d'Acupe, Etat de Bahia, Brasil. Notes du Laboratoire de Paleontologie de l'Universit de Geneve, 4, 1-17. 